\title{
Zobellella aerophila sp. nov., isolated from seashore sand, and emended description of the genus Zobellella
}

\author{
Correspondence \\ Jongsik Chun \\ jchun@snu.ac.kr
}

\author{
Hana Yi, ${ }^{1}$ Jaekyeong Song, ${ }^{2}$ Jang-Cheon $\mathrm{Cho}^{3}$ and Jongsik Chun ${ }^{1,4}$ \\ ${ }^{1}$ Institute of Molecular Biology and Genetics, Seoul National University, 599 Kwanak-ro, \\ Kwanak-gu, Seoul 151-742, Republic of Korea \\ ${ }^{2}$ National Agrobiodiversity Center, NAAS, RDA, Suwon, 441-853, Republic of Korea \\ ${ }^{3}$ Division of Biology and Ocean Sciences, Inha University, Incheon 402-751, Republic of Korea \\ ${ }^{4}$ School of Biological Sciences \& Institute of Bioinformatics (BIOMAX), Seoul National University, \\ 599 Kwanak-ro, Kwanak-gu, Seoul 151-742, Republic of Korea
}

\begin{abstract}
A strictly aerobic, nitrate-reducing, motile, rod-shaped member of the class
Gammaproteobacteria, designated strain $\mathrm{JC} 2671^{\top}$, was isolated from a seashore sand sample from Dokdo, Korea. The isolate reduced nitrate to nitrite, but not to nitrogen, and required $\mathrm{NaCl}$ for growth. 16S rRNA gene sequence analysis indicated that the isolate belonged to the genus Zobellella within the order Alteromonadales with sequence similarities of $96.0-97.6 \%$ to strains of Zobellella species with validly published names. However, in DNA-DNA hybridization studies, a low genomic relatedness (43\%) between strain $\mathrm{JC} 2671^{\top}$ and the type strain of Zobellella denitrificans indicated that the isolate represented a novel genomic species. The polar lipid pattern (phosphatidylethanolamine and phosphatidylglycerol), predominant cellular fatty acids $\left[\mathrm{C}_{16: 0}\right.$, summed feature $3\left(\mathrm{C}_{16: 1} \omega 6 \mathrm{c}\right.$ and/or $\left.\mathrm{C}_{16: 1} \omega 7 \mathrm{c}\right)$ and summed feature $8\left(\mathrm{C}_{18: 1} \omega 6 \mathrm{c}\right.$ and/ or $\left.\mathrm{C}_{18: 1} \omega 7 \mathrm{c}\right)$ ] and the DNA G $+\mathrm{C}$ content $(59 \mathrm{~mol} \%)$ of the novel strain were consistent with its assignment to the genus Zobellella. In contrast, a number of phenotypic characteristics, namely a requirement of $\mathrm{NaCl}$ for growth, the inability to grow under facultatively anaerobic conditions, the absence of nitrite reduction and differences in carbohydrate utilization and enzymic activities, clearly distinguished the novel isolate from other species of the genus Zobellella. Data from this polyphasic study indicate that strain $\mathrm{JC}_{2} 671^{\top}$ represents a novel species in the genus Zobellella, for which the name Zobellella aerophila sp. nov. is proposed. The type strain is JC2671 ${ }^{\top}$ $\left(=\right.$ KACC $\left.15081^{\top}=J C M 17110^{\top}\right)$. The description of the genus Zobellella has been emended accordingly.
\end{abstract}

The genus Zobellella was proposed by Lin \& Shieh (2006) to accommodate two novel Gram-negative, motile by a polar flagella, heterotrophic, denitrifying and facultatively anaerobic bacteria, namely Zobellella denitrificans and Zobellella taiwanensis. This genus belongs to the order Alteromonadales (Bowman \& McMeekin, 2005), with members of the genera Oceanimonas and Oceanisphaera as its closest neighbours. During a recent study of the microbial diversity of Dokdo, Korea, a novel Zobellella-like

\footnotetext{
Abbreviations: PE, phosphatidylethanolamine; PG, phosphatidylglycerol; TEM, transmission electron microscopy.

The GenBank/EMBL/DDBJ accession number for the 16S rRNA gene sequence of strain $\mathrm{JC} 2671^{\top}$ is $\mathrm{HM} 475140$.

Two supplementary figures are available with the online version of this
} paper. denitrifying bacterial strain was isolated and subjected to a comprehensive taxonomic study.

A Gram-reaction-negative strain, designated $\mathrm{JC} 2671^{\mathrm{T}}$, was isolated from a seashore sand sample from Dokdo, Korea $\left(37^{\circ} 14^{\prime} 28^{\prime \prime} \mathrm{N} 131^{\circ} 52^{\prime} 9^{\prime \prime} \mathrm{E}\right)$, using a standard dilution plating method on marine agar 2216 (MA; BD). The isolate was cultured routinely on MA and maintained as glycerol suspensions $(20 \%, \mathrm{w} / \mathrm{v})$ at $-80{ }^{\circ} \mathrm{C}$. The type strains of the two species of the genus Zobellella with validly published names, $Z$. denitrificans $Z \mathrm{ZD}^{\mathrm{T}}\left(=\mathrm{JCM} 13380^{\mathrm{T}}\right)$ and $Z$. taiwanensis $\mathrm{ZT}^{\mathrm{T}}\left(=\mathrm{JCM} 13381^{\mathrm{T}}\right)$, were also evaluated under identical experimental conditions to those used on strain JC2671 ${ }^{\mathrm{T}}$.

The 16S rRNA gene was enzymically amplified from a single colony. Primers, PCR conditions and sequencing methods have been described previously (Chun \& 
Goodfellow, 1995). Preliminary sequence identification against the 16S rRNA gene sequences held in the EzTaxon database of prokaryotic type strains with validly published names (Chun et al., 2007) indicated that our isolate showed a close relationship with members of the genus Zobellella. The nearly complete 16S rRNA gene sequence (1409 bp) of strain JC267 $1^{\mathrm{T}}$ was aligned manually against sequences of species of the genus Zobellella and representatives of phylogenetically related genera within the order Alteromonadales using the bacterial 16S rRNA secondary structure model. The regions available for all sequences (positions 93-820, 850-1126 and 1132-1388; based on the Escherichia coli numbering system) showed unambiguous alignment and were used to construct phylogenetic trees. Alignment and neighbour-joining (Saitou \& Nei, 1987) analyses were carried out using the program jPHYDIT (Jeon et al., 2005). An evolutionary distance matrix for the neighbour-joining tree was generated according to the model of Jukes \& Cantor (1969) and the resultant tree topology was evaluated by bootstrap analyses (Felsenstein, 1985) based on 1000 resamplings. A Bayesian inference was performed with the program MrBayes 3.1.2 (Ronquist \& Huelsenbeck, 2003) with an evolutionary model of the General Time Reversible model with a gamma-distributed rate variation. The program was run for 1000000 generations with a sample frequency of 100 and a burnin of 200. A maximum-likelihood (Felsenstein, 1993) tree was constructed using PAUP 4.0 (Swofford, 1998) with a heuristic search option and 1000 replicates. On the basis of $16 \mathrm{~S}$ rRNA gene analyses, strain JC2671 ${ }^{\mathrm{T}}$ showed highest sequence similarity to $Z$. denitrificans $Z \mathrm{ZD1}^{\mathrm{T}}(97.6 \%)$ and $Z$. taiwanensis $\mathrm{ZT}^{\mathrm{T}}{ }^{\mathrm{T}}(96.0 \%)$, followed by members of the genera Oceanisphaera (95.3-95.7\%) and Oceanimonas (95.5-95.6\%). No other taxon showed $>93 \%$ sequence similarity to the novel isolate. This close relationship between strain JC2671 ${ }^{\mathrm{T}}$ and members of the abovementioned genera was also evident in the phylogenetic tree (Fig. 1). Based on all three tree-inferring methods used in this study, the genera Zobellella, Oceanimonas and Oceanisphaera, including strain JC2671 ${ }^{\mathrm{T}}$, formed a monophyletic clade with $100 \%$ bootstrap support. Within this suprageneric clade, strain $\mathrm{JC} 2671^{\mathrm{T}}$ and the type species of the genus Zobellella, $Z$. denitrificans, were consistently recovered as a monophyletic clade supporting the assignment of the novel isolate to the genus Zobellella. However, the monophyly of the genus Zobellella was hampered by $Z$. taiwanensis, the branching position of which varied depending on the tree inferring algorithm used. In the Bayesian tree, $Z$. taiwanensis branched as a sister group of the clade containing the genera Oceanimonas and Oceanisphaera rather than as a sister group of the clade containing strain $\mathrm{JC} 2671^{\mathrm{T}}$ and $Z$. denitrificans. Furthermore, in the maximum-likelihood tree, Oceanimonas smirnovii formed a monophyletic clade together with strain $\mathrm{JC} 2671^{\mathrm{T}}$ and with the two recognized species of the genus Zobellella. This indicated that the generic status of the genera Zobellella and Oceanimonas is questionable. Further study is needed to clarify the taxonomic position of

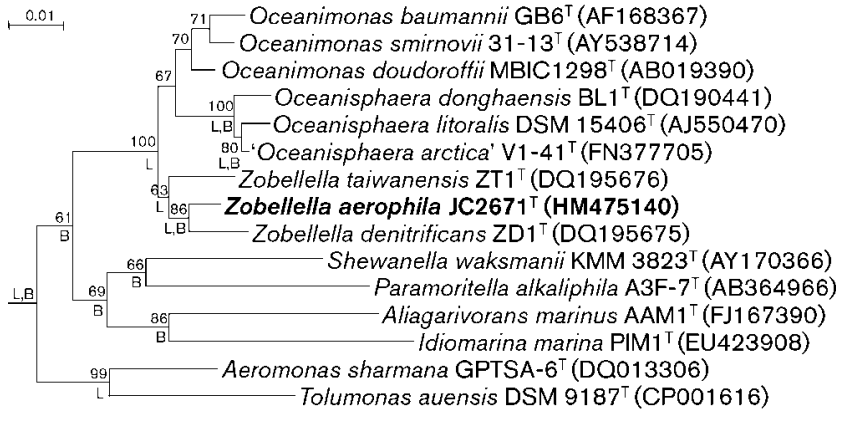

Fig. 1. Neighbour-joining tree based on nearly complete $16 \mathrm{~S}$ rRNA gene sequences. Numbers at the nodes are percentages of bootstrap support (>50\%) from 1000 resampled datasets. Letters at the nodes indicate that the corresponding nodes (groupings) were also recovered in Bayesian (B) and/or in maximum-likelihood $(\mathrm{L})$ tree-inferring methods. Helicobacter pylori NCTC $11637^{\top}$ (Z25741) was used as an outgroup (not shown). Bar, 0.01 substitutions per nucleotide position.

these genera. The phylogenetic distinctiveness and robustness of the suprageneric clade containing the genera Zobellella, Oceanimonas and Oceanisphaera suggests the possibility that these three genera could be combined into a single genus in the future.

As the isolate shared a high 16S rRNA gene similarity of $97.6 \%$ with $Z$. denitrificans $\mathrm{ZD1}^{\mathrm{T}}$, genomic relatedness between the two strains was further examined using the method of Huß et al. (1983) with modifications (Yi \& Chun, 2006). The two strains shared a low DNA-DNA relatedness value $(43 \%)$, which is well below the threshold of $70 \%$ recommended for the delineation bacterial species (Wayne et al., 1987). It was clear from DNA-DNA hybridization studies that strain $\mathrm{JC} 2671^{\mathrm{T}}$ represents a novel genomic species.

Cell morphology and motility were examined by using transmission electron (TEM) and phase-contrast microscopy, respectively, after growth on MA at $30{ }^{\circ} \mathrm{C}$ for 2 days. For TEM observation, negative staining with uranyl acetate was performed (Supplementary Fig. S1, available in IJSEM Online). Growth at 5, 10, 15, 20, 25, 30, 35, 40, 45 and $50{ }^{\circ} \mathrm{C}$, at $\mathrm{pH} 5-10.5$ (intervals of $0.5 \mathrm{pH}$ units; adjusted with $10 \mathrm{M} \mathrm{KOH}$ or $\mathrm{HCl}$ ) and in $0,0.5,1,2,3,4,5,7,10$, 12,15 and $20 \%(\mathrm{w} / \mathrm{v}) \mathrm{NaCl}$ was assessed using synthetic ZoBell broth (ZoBell, 1941) to determine the ranges for growth. Growth under anaerobic conditions was assessed using anaerobically prepared MA in an anaerobic chamber $\left(\mathrm{CO}_{2} / \mathrm{H}_{2} / \mathrm{N}_{2}, 10: 10: 80, \mathrm{v} / \mathrm{v} / \mathrm{v}\right)$ (Sheldon Manufacturing). Facultative anaerobic growth in the presence of $\mathrm{KNO}_{3}$ was determined using anaerobically prepared MA. Although the two recognized species of the genus Zobellella were capable of reducing nitrate to nitrogen, strain JC2671 ${ }^{\mathrm{T}}$ reduced nitrate to nitrite only. In addition, the two recognized species of the genus Zobellella were capable of 
facultative anaerobic growth in the presence of $\mathrm{KNO}_{3}$, whereas the novel isolate was not.

Standard physiological and biochemical tests were performed as described previously (Smibert \& Krieg, 1994). Hydrolysis of alginic acids, casein, microcrystalline cellulose, chitin, egg yolk, elastin, pectin, starch, and Tweens 20, 40, 60 and 80 was tested using MA as the basal medium. Decomposition of adenine, hypoxanthine, L-tyrosine and xanthine was tested using MA according to Gordon et al. (1974). Other enzymic activities were determined using the API $20 \mathrm{NE}$, API $20 \mathrm{E}$ and API ZYM kits (bioMérieux). Acid production by fermentation of carbon sources was tested by using the API $50 \mathrm{CH}$ with $\mathrm{CHB} / \mathrm{E}$ medium (bioMérieux) supplemented with halfstrength seawater. The API kits were inoculated with a heavy bacterial suspension in half-strength artificial seawater and data were recorded for up to three consecutive days.

The DNA G + C content was determined by the thermal denaturation method (Marmur \& Doty, 1962). For fatty acid analysis, strain JC2671 ${ }^{\mathrm{T}}$ and the two reference strains were grown on MA at $30{ }^{\circ} \mathrm{C}$ for 2 days. Extraction of fatty acid methyl esters and GC separation were performed by using the Instant FAME method of the Microbial Identification System (MIDI) version 6.1 and the RTSBA6 6.10 database. Polar lipids were extracted, purified and identified as described by Minnikin et al. (1984).

The results of morphological, cultural, biochemical, physiological and chemotaxonomic tests are presented in the species description.

The polar lipid compositions of the isolate and the two recognized species of the genus Zobellella were very similar with phosphatidylethanolamine (PE) and phosphatidylglycerol (PG) as major components (Supplementary Fig. S2). However, this result was not congruent with the previous report of Lin \& Shieh (2006) which described PE, PG and diphosphatidylglycerol as the major polar lipids of the two reference species. Thus, an emended description of the genus Zobellella is proposed.

Phylogenetic analyses based on 16S rRNA gene sequences showed that strain JC2671 ${ }^{\mathrm{T}}$ belonged to the genus Zobellella, representing a distinct phyletic line within the genus. Although the sequence similarity between the isolate and $Z$. denitrificans $\mathrm{ZD1}^{\mathrm{T}}$ is relatively high $(97.6 \%)$, the low DNA-DNA reassociation value ( $43 \%$ ), which is well below the threshold of $70 \%$, recommended for the delineation of bacterial species (Wayne et al., 1987), indicated that the isolate represents a novel genomic species of the genus Zobellella. In addition, a number of differentiating phenotypic characteristics (Table 1), such as a requirement of $\mathrm{NaCl}$ for growth, an inability to grow under facultatively anaerobic conditions and an absence of nitrite reduction, as well as differences in utilization of fermentable carbohydrates, enzymic activities, fatty acid profiles and $\mathrm{G}+\mathrm{C}$ contents, clearly supported assignment of the isolate to a novel species of the genus Zobellella, for which the name Zobellella aerophila sp. nov. is proposed.

\section{Emended description of the genus Zobellella}

The description of the genus is as given previously (Lin \& Shieh, 2006) but with the following amendments. Facultative anaerobes or strict aerobes. Requires $\mathrm{NaCl}$ for growth or for growth stimulation. Major polar lipids are $\mathrm{PE}$ and PG. Major fatty acids are summed feature 3 $\left(\mathrm{C}_{16: 1} \omega 6 c\right.$ and/or $\left.\mathrm{C}_{16: 1} \omega 7 c\right)$, summed feature $8\left(\mathrm{C}_{18: 1} \omega 6 c\right.$ and/or $\left.\mathrm{C}_{18: 1} \omega 7 c\right)$ and $\mathrm{C}_{16: 0}$. The $\mathrm{G}+\mathrm{C}$ content of the genomic DNA is $59-64 \mathrm{~mol} \%$.

\section{Description of Zobellella aerophila sp. nov.}

Zobellella aerophila (ae.ro' phi.la. Gr. masc. n. aer air; Gr. adj. philos loving; N.L. fem. adj. aerophila air-loving).

Cells are Gram-reaction-negative, motile rods, $0.5-1.1 \times 1.0$ $6.9 \mu \mathrm{m}$, with a single polar flagellum. Catalase- and oxidasepositive, aerobic and nitrate-reducing. Reduces nitrate to nitrite. Facultative anaerobic growth in the presence of $\mathrm{KNO}_{3}$ is not observed. Grows at $5-45{ }^{\circ} \mathrm{C}$ (optimum 30 $35{ }^{\circ} \mathrm{C}$ ), at pH $5-10.5$ (optimum $\mathrm{pH} 7$ ) and in $0.5-5 \% \mathrm{NaCl}$ (optimum 1-3\%). Does not grow in the absence of $\mathrm{NaCl}$. Colonies on MA at $30{ }^{\circ} \mathrm{C}$ are cream-coloured, convex and circular with entire margins. Positive for arginine dihydrolase, lysine decarboxylase, ornithine decarboxylase and urease activities. Utilizes citrate. Positive for VogesProskauer reaction. Does not show $\beta$-galactosidase or tryptophan deaminase activity. Does not produce hydrogen sulfide. Acid is not produced from glucose and indole is not produced from tryptophan. Decomposes Tween 20, adenine, hypoxanthine, L-tyrosine and xanthine. Decomposes gelatin in the API 20 E gallery but not in the API 20 NE gallery. Does not decompose agar, alginic acids, casein, cellulose, chitin, egg yolk, elastin, aesculin, pectin, starch, or Tweens 40,60 or 80. In the API ZYM system, positive for alkaline phosphatase and leucine arylamidase activities and negative for esterase (C4), esterase lipase (C8), lipase (C14), valine arylamidase, cystine arylamidase, trypsin, $\alpha$-chymotrypsin, acid phosphatase, naphthol-AS-BI-phosphohydrolase, $\alpha$ - and $\beta$-galactosidase, $\beta$-glucuronidase, $\alpha$ - and $\beta$-glucosidase, $N$-acetyl $\beta$ glucosaminidase, $\alpha$-mannosidase and $\alpha$-fucosidase activities. In the API $50 \mathrm{CH}$ system, positive for fermentation of glycerol, D-fructose, inositol, D-mannitol and $\mathrm{N}$ acetylglucosamine; negative for fermentation of erythritol, D-arabinose, L-arabinose, D-ribose, D- and L-xylose, Dadonitol, methyl $\beta$-D-xylopyranoside, D-galactose, D-glucose, D-mannose, L-sorbose, L-rhamnose, dulcitol, D-sorbitol, methyl $\alpha$-D-mannopyranoside, methyl $\alpha$-D-glucopyranoside, amygdalin, arbutin, aesculin ferric citrate, salicin, cellobiose, maltose, lactose (bovine origin), melibiose, sucrose, trehalose, inulin, melezitose, raffinose, starch, glycogen, xylitol, gentiobiose, turanose, D-lyxose, D-tagatose, D- and L-fucose, D- and L-arabitol, potassium gluconate, potassium 2ketogluconate or potassium 5-ketogluconate. The major fatty acids are $\mathrm{C}_{16: 0}$, summed feature $3\left(\mathrm{C}_{16: 1} \omega 6 c\right.$ and/or $\left.\mathrm{C}_{16: 1} \omega 7 c\right)$ and summed feature $8 \quad\left(\mathrm{C}_{18: 1} \omega 6 c\right.$ and/or $\mathrm{C}_{18: 1}(\omega 7 c)$. The phospholipids are composed of PE, PG and three unidentified aminolipids. 
Table 1. Phenotypic characteristics that differentiate strain JC2671 ${ }^{\top}$ from other species of the genus Zobellella

Strains: 1 , JC2671 ${ }^{\mathrm{T}} ; 2$, Z. denitrificans $\mathrm{ZD1}^{\mathrm{T}} ; 3$, Z. taiwanensis $\mathrm{ZT}^{\mathrm{T}}$. All data are from this study unless indicated otherwise. All strains were positive for the following characteristics: catalase and oxidase activities, decomposition of adenine, hypoxanthine, L-tyrosine and xanthine, utilization of citrate, acetoin production, alkaline phosphatase and leucine arylamidase activities and utilization of D-fructose, inositol, D-mannitol and $N$-acetylglucosamine. All strains were negative for the following characteristics: Gram-reaction, decomposition of agar, alginic acid, casein, cellulose, chitin, egg yolk, elastin, aesculin, pectin, starch, and Tweens 40, 60 and 80, production of hydrogen sulfide and indole, tryptophan deaminase, esterase (C4), esterase lipase (C8), lipase (C14), cystine arylamidase, trypsin, $\alpha$ chymotrypsin, $\alpha$-and $\beta$-galactosidase, $\beta$-glucuronidase, $\beta$-glucosidase, $N$-acetyl- $\beta$-glucosaminidase, $\alpha$-mannosidase and $\alpha$-fucosidase activities and utilization of D-arabinose, L-arabinose, D- and L-xylose, methyl $\beta$-D-xylopyranoside, D-mannose, L-sorbose, L-rhamnose, dulcitol, D-sorbitol, methyl $\alpha$-D-mannopyranoside, amygdalin, arbutin, aesculin ferric citrate, cellobiose, lactose, inulin, glycogen, gentiobiose, D-lyxose, D-tagatose, D- and L-fucose, D-arabitol, potassium 2-ketogluconate and potassium 5-ketogluconate. +, Positive; -, negative; $\mathrm{w}$, weakly positive; $\mathrm{v}$, variable.

\begin{tabular}{|c|c|c|c|}
\hline Characteristic & 1 & 2 & 3 \\
\hline Growth in $0 \% \mathrm{NaCl}$ & - & + & + \\
\hline Anaerobic growth on MA & - & $\mathrm{W}$ & $\mathrm{W}$ \\
\hline Facultative anaerobic growth with $\mathrm{KNO}_{3}$ & - & + & + \\
\hline Reduction of nitrate to nitrite & + & - & - \\
\hline Reduction of nitrate to nitrogen & - & + & + \\
\hline Fermentation of glucose & - & + & + \\
\hline Decomposition of Tween 20 & + & - & - \\
\hline Decomposition of gelatin & $\mathrm{V}$ & - & - \\
\hline $\begin{array}{l}\text { Activities of arginine dihydrolase, lysine } \\
\text { decarboxylase, ornithine decarboxylase, urease }\end{array}$ & + & - & - \\
\hline \multicolumn{4}{|l|}{ API ZYM: } \\
\hline $\begin{array}{l}\text { Valine arylamidase, naphthol-AS-BI- } \\
\text { phosphohydrolase }\end{array}$ & - & $\mathrm{w}$ & $\mathrm{w}$ \\
\hline Acid phosphatase, $\alpha$-glucosidase & - & + & $\mathrm{W}$ \\
\hline \multicolumn{4}{|l|}{ Fermentation of carbohydrates (API 50CH): } \\
\hline Glycerol & + & + & - \\
\hline $\begin{array}{l}\text { Erythritol, D-galactose, salicin, melibiose, } \\
\text { trehalose, melezitose, raffinose, turanose, } \\
\text { potassium gluconate }\end{array}$ & - & + & - \\
\hline $\begin{array}{l}\text { D-Ribose, D-glucose, maltose, methyl } \\
\alpha \text {-D-glucopyranoside, sucrose, starch }\end{array}$ & - & + & + \\
\hline D-Adonitol, xylitol, L-arabitol & - & - & + \\
\hline \multicolumn{4}{|l|}{ Fatty acids:* } \\
\hline $\mathrm{C}_{12: 0}$ & 6.1 & 5.8 & 5.0 \\
\hline $\mathrm{C}_{16: 0}$ & 22.8 & 17.2 & 17.2 \\
\hline $\mathrm{C}_{17: 0}$ & 2.8 & 1.6 & 0.5 \\
\hline iso- $\mathrm{C}_{16: 0}$ & 2.0 & 1.7 & 0.5 \\
\hline $\mathrm{C}_{17: 0}$ cyclo & 0.0 & 5.0 & 0.0 \\
\hline iso- $\mathrm{C}_{17: 0}$ & 0.9 & 1.2 & 2.5 \\
\hline $\mathrm{C}_{17: 1} \omega 8 c$ & 1.4 & 0.6 & 0.3 \\
\hline $\mathrm{C}_{19: 0}$ cyclo $\omega 8 \mathrm{c}$ & 0.0 & 1.7 & 0.0 \\
\hline
\end{tabular}

Table 1. cont.

\begin{tabular}{|lccc|}
\hline Characteristic & $\mathbf{1}$ & $\mathbf{2}$ & $\mathbf{3}$ \\
\hline Summed features $\dagger$ & & & \\
2 & 6.7 & 6.1 & 5.9 \\
3 & 29.7 & 23.8 & 28.9 \\
8 & 22.7 & 30.0 & 33.5 \\
9 & 0.3 & 0.8 & 1.5 \\
DNA G+C content (mol\%) & 59 & $64 \ddagger$ & $62 \ddagger$ \\
\hline
\end{tabular}

${ }^{\star}$ Fatty acids amounting to $<1 \%$ of the total fatty acids in all strains were not included.

$\dagger$ Summed features are groups of two or three fatty acids that cannot be separated by GLC with the MIDI system. Summed feature 2 comprises $\mathrm{C}_{14: 0}$ 3-OH and/or iso- $\mathrm{C}_{16: 1} \mathrm{I}$; summed feature 3 comprises $\mathrm{C}_{16: 1} \omega 6 c$ and/or $\mathrm{C}_{16: 1} \omega 7 c$, summed feature 8 comprises $\mathrm{C}_{18: 1} \omega 6 c$ and/or $\mathrm{C}_{18: 1} \omega 7 c$; summed feature 9 comprises $\mathrm{C}_{16: 0}$ 10-methyl and/or iso- $\mathrm{C}_{17: 1} \omega 9 c$.

$\ddagger$ Data from Lin \& Shieh (2006).

The type strain, JC2671 ${ }^{\mathrm{T}}\left(=\mathrm{KACC} 15081^{\mathrm{T}}=\mathrm{JCM} 17110^{\mathrm{T}}\right)$, was isolated from a seashore sand sample from Dokdo island, Korea. The DNA G + C content of the type strain is $59 \mathrm{~mol} \%$.

\section{Acknowledgements}

This work was supported by the Priority Research Centers Program (no. 2008-005J00201) and a National Research Foundation grant (no. 2010-0017955) funded by the Korean Government (MEST), and a grant from Regional SubGenBank Support Program of Rural Development Administration, Republic of Korea.

\section{References}

Bowman, J. P. \& McMeekin, T. A. (2005). Order X. Alteromonadales ord. nov. In Bergey's Manual of Systematic Bacteriology, 2nd edn, vol. 2, pp. 443. Edited by D. J. Brenner, N. R. Krieg, J. T. Staley \& G. M. Garrity. New York: Springer.

Chun, J. \& Goodfellow, M. (1995). A phylogenetic analysis of the genus Nocardia with $16 \mathrm{~S}$ rRNA gene sequences. Int J Syst Bacteriol 45, 240-245.

Chun, J., Lee, J. H., Jung, Y., Kim, M., Kim, S., Kim, B. K. \& Lim, Y. W. (2007). EzTaxon: a web-based tool for the identification of prokaryotes based on $16 \mathrm{~S}$ ribosomal RNA gene sequences. Int J Syst Evol Microbiol 57, 2259-2261.

Felsenstein, J. (1985). Confidence limits on phylogenies: an approach using the bootstrap. Evolution 39, 783-791.

Felsenstein, J. (1993). PHYLIP (phylogenetic inference package) version 3.5.1. Distributed by the author. Department of Genome Sciences, University of Washington, Seattle, USA.

Gordon, R. E., Barnett, D. A., Handerhan, J. E. \& Pang, C. H.-N. (1974). Nocardia coeliaca, Nocardia autotrophica, and the nocardin strain. Int J Syst Bacteriol 24, 54-63.

Huß, V. A. R., Festl, H. \& Schleifer, K. H. (1983). Studies on the spectrophotometric determination of DNA hybridization from renaturation rates. Syst Appl Microbiol 4, 184-192.

Jeon, Y. S., Chung, H., Park, S., Hur, I., Lee, J. H. \& Chun, J. (2005). jPHYDIT: a JAVA-based integrated environment for molecular phylogeny of ribosomal RNA sequences. Bioinformatics 21, 3171-3173. 
Jukes, T. H. \& Cantor, C. R. (1969). Evolution of protein molecules. In Mammalian Protein Metabolism, vol. 3, pp. 21-132. Edited by H. N. Munro. New York: Academic Press.

Lin, Y. T. \& Shieh, W. Y (2006). Zobellella denitrificans gen. nov., sp. nov. and Zobellella taiwanensis sp. nov., denitrifying bacteria capable of fermentative metabolism. Int J Syst Evol Microbiol 56, 1209-1215.

Marmur, J. \& Doty, P. (1962). Determination of the base composition of deoxyribonucleic acid from its thermal denaturation temperature. J Mol Biol 5, 109-118.

Minnikin, D. E., O'Donnell, A. G., Goodfellow, M., Alderson, G., Athalye, M., Schaal, A. \& Parlett, J. H. (1984). An integrated procedure for the extraction of bacterial isoprenoid quinones and polar lipids. J Microbiol Methods 2, 233-241.

Ronquist, F. \& Huelsenbeck, J. P. (2003). MrBayes 3: Bayesian phylogenetic inference under mixed models. Bioinformatics 19, 1572-1574.

Saitou, N. \& Nei, M. (1987). The neighbor-joining method: a new method for reconstructing phylogenetic trees. Mol Biol Evol 4, 406-425.
Smibert, R. M. \& Krieg, N. R. (1994). Phenotypic characterization. In Methods for General and Molecular Bacteriology, pp. 607-654. Edited by P. Gerhardt, R. G. E. Murray, W. A. Wood \& N. R. Krieg. Washington, DC: American Society for Microbiology.

Swofford, D. L. (1998). Phylogenetic analysis using parsimony (PAUP), version 4. Sunderland, MA: Sinauer Associates.

Wayne, L. G., Brenner, D. J., Colwell, R. R., Grimont, P. A. D., Kandler, O., Krichevsky, M. I., Moore, L. H., Moore, W. E. C., Murray, R. G. E. \& other authors (1987). International Committee on Systematic Bacteriology. Report of the ad hoc committee on reconciliation of approaches to bacterial systematics. Int J Syst Bacteriol 37, 463464.

Yi, H. \& Chun, J. (2006). Thalassobius aestuarii sp. nov., isolated from tidal flat sediment. J Microbiol 44, 171-176.

ZoBell, C. E. (1941). Studies on marine bacteria. I. The cultural requirements of heterotrophic aerobes. J Mar Res 4, 42-75. 